\title{
Using Humor in Language Classrooms: Greasing the Wheels or Putting a Spanner in the Works? A Study on Humor Styles of Turkish EFL Instructors
}

\author{
Mehdi Solhi Andarab a * (D), Aynur Kesen Mutlu a ${ }^{\dagger}$ \\ a The Department of English Language Teaching, School of Education, Istanbul Medipol University \\ Received 04 February 2018 | Received in revised form 05 June 2018 | Accepted 21 November 2018
}

\begin{abstract}
APA Citation:
Solhi Andarab, M., \& Mutlu, A. (2019). Using humor in language classrooms: Greasing the wheels or putting a spanner in the works? A study on humor styles of Turkish EFL instructors. Eurasian Journal of Applied Linguistics, 5(1), 23-39. Doi: 10.32601/ejal.543776
\end{abstract}

\begin{abstract}
Humor has often been seen as an important element in the learning process, facilitating both teaching and learning. Nevertheless, the utilization of humor in the educational setting has had its opponents. In recent years, many attempts have been made to conceptualize the various forms of humor implemented in the practice of education. Despite a myriad of studies aimed at linking humor with personality traits, there seem a dearth number of research studies addressing the multifaceted humor styles of EFL instructors while interacting with the students in the classroom. There have been a number of scales thought-up in order to best assess the humor styles of the individual. However, the one identified by Martin et al. (2003) attempts to deal with the functions of humor, rather than particular personalities it may or may not represent. The four specific humor styles identified in this scale encompass two benign (affiliative and self-enhancing), and two injurious (aggressive and self-defeating) humor styles. The present study seeks to examine the humor styles adopted by English language instructors in Turkey by investigating (1) whether there is a difference between male and female instructors with regard to employing humor, (2) whether the educational level of the participants influences their tendency to use humor while interacting with the students in the classroom, and (3) whether the age of the instructors is an influential factor in adopting various styles of humor. A total of 64 English language instructors working at private and state universities in Turkey completed a standardized form of the Humor Styles Questionnaire (HSQ) online. Results indicated no significant difference between male and female instructors with regard to adopting humor styles in the classroom. Nor were there any differences between instructors of varying educational level in terms of the use of humor styles. In addition, no differences were seen according to age.
\end{abstract}

(C) 2019 EJAL \& the Authors. Published by Eurasian Journal of Applied Linguistics (EJAL). This is an open-access article distributed under the terms and conditions of the Creative Commons Attribution license (CC BY-NC-ND) (http://creativecommons.org/licenses/by-nc-nd/4.0/).

Keywords: EFL classroom; Humor styles; the Humor Styles Questionnaire (HSQ)

\footnotetext{
* Corresponding author. Tel.: +90216 6815100 (1717)

E-mail address: solhi.mehdi@gmail.com

† $\underline{\text { aynur.kesen@gmail.com }}$
} 


\section{Introduction}

The foreign language teaching classroom possesses a fundamentally different nature vis-à-vis most other classrooms, in that the teaching language - merely a tool used to convey the subject in most examples - in the language teaching environment is both the medium of instruction and the content to be learnt in and of itself (Huy Hohang \& Petraki, 2016). McNamara (2004) similarly refers to the undeniable role of a language teacher beyond teaching subject matter, stating that teaching communicative skills incorporates the whole personality of the teacher. He adds that personality traits as rapport and humor are significant in creating collaborative environment for learning in the classroom and excluding them are less likely to pave the way for the learners to willingly interact in the classroom. This is owing to that fact that successful communication is a mutual responsibility on the part of both speaker and listener, and the personality traits of the speaker may be a triggering factor for the listener's preparedness to understand. Therefore, humor, as an intrinsic component of the human language, can be used to teach the language itself besides being utilized to cater for an environment which fosters learning.

\section{Literature review}

\subsection{Definition of humor}

Humor has traditionally been conceived as a mechanism for coping with life's difficulties and situational problems (Thorson \& Powell, 1993). There are many different definitions of humor. Merriam-Webster's dictionary interpretation, for instance, summarizes the phenomena as simply "the ability to be funny or to be amused by things that are funny". Over three decades ago, meanwhile, Martin and Lefcourt (1984) defined a sense of humor in terms of the frequency with which a person smiles, laughs, and otherwise displays happiness or laughter in different situations. Concerning its usage in language teaching, humor can be defined as teacher- or student-triggered efforts to provoke laughter and amusement in the classroom. These attempts can result from the classroom interactions, teaching materials, the lesson content, and eventually lead to laughter or smiling (Huy Hoang \& Petraki, 2006, p. 2). Humor, as Garner (2005, p. 1) puts, "is most effective when it is appropriate to the audience, targeted to the topic, and placed in the context of the learning experience".

\subsection{The effect of humor on language learners}

In his book, Professors are from Mars, students are from Snickers, Berk (1998) accentuates the psychological and physiological effects of humor on the language learners. He clarifies that classrooms in which humor is integrated in the process of learning are likely to lower anxiety, relieve stress, develop self-esteem, and build up self-motivation. With regard to the physiological effects of humor, he points out that humor and laughter can maximize learning through promoted respiratory efficiency 
and blood circulation, lower pulse rate and blood pressure, increased oxygen levels in the blood, and eventually causing endorphins to be released into the bloodstream. Given any technique which reduces stress and learner anxiety in the classroom can be considered an invaluable resource for promoting a good classroom atmosphere, humor certainly proves its technical worth (Huy Hoang \& Petraki, 2006). A great number of scholars (e.g., Askildson, 2005; Garner, 2003; Harmer, 2007; Oxford, 1999) similarly assert the importance of humor and its ability to pave the way for enhancing learning and reducing anxiety, and argue in favor of a relaxing and psychologically secure, and supportive classroom atmosphere that is likely to reassure risk-taking, and enhance learners' motivation and self-confidence. Dornyei (2001, p. 29) also advocates the integration of humor in the process of teaching and the establishment of an enjoyable classroom atmosphere and considers it one amongst "motivational teaching practice". Similarly, Garner (2003) maintains that the application of contextually suitable humor has been indicated to improve the classroom atmosphere and ease the process of language learning, paving the way for the individuals to perceive information or circumstances with a new perspective perhaps leading to fresh insights.

\subsection{Cautions against using humor}

Despite the above-mentioned facilitating effects of using humor in language teaching, another group of scholars (e.g., Garner, 2003, 2006; Gonzalez, 2014; Steele, 1998; Sudol, 1981) urge caution against the potential consequences of using humor in the classroom. Garner (2003, p. 4), for instance, urges cautions against tendentious humor, warning that humor should be used with care, as humor can "be highly personal, subjective, and contextual". Therefore, teachers cannot always predict the way it will be interpreted. The words that an individual might consider ironic, funny, or humorous are likely to be interpreted or understood by others as banal or malicious. This is due to the fact that "everyone has a unique perception as to what is humorous", so consciousness and meticulousness should be the guiding principle while using humor. Gonzalez (2014) also posits that so much as an ill-timed smile on the part of the teacher may go so way to distracting the students, thus derailing the learning process for a period. She emphasizes that to make the classroom more enjoyable, the instructor can indicate to their students they have a sense of humor while appreciating theirs; however, all must learn there is an appropriate time and place for it. Echoing Garner (2006), Gonzalez (2014), Steele (1998), and Sudol (1981) highlight that content-irrelevant humor in a classroom setting can be distracting and irrelevant. Thus, humor should be related to the lesson. Huy Hoang and Petraki (2016) similarly emphasize that taboo topics in humor should be avoided, and the content of humor should be appropriate to students' levels, personalities and ages. They advise that teachers establish good rapport and mutual trust with students, so that humor is more likely to be welcomed, and less likely to be threatening when it fails! Huy Hoang and Petraki (2016, p. 12) also add that humor "should not be used as a form of criticism, no matter whether against an individual student, a group of students, departments, schools, or society in general". 


\subsection{Studies on humor in the language classroom}

A plethora of studies conducted to investigate the pedagogical implications and invaluable effects of using humor in language teaching underline the benefits accrued by the use of humor (e.g., Berk, 1998; Dornyei, 2001; Garner, 2003, 2006; Huy Hoang \& Petraki, 2006). One of the first empirical studies arguing in favor of the benefits of using humor in the process of teaching is Ziv's (1988) study examining the test results of two groups of undergraduate students taught by one teacher using relevant humor and one using no humor. According to the results, the first group learning with humor achieved higher test results. The jokes and humor used in the lectures for the second group was totally related to the learning materials and highly relevant to the course content. Three to four instances of humor (jokes, cartoons or anecdotes) per hour were set as ideal. Garner's (2006) study revealed that the participants in the humor group had higher ratings for overall opinion of the lesson, and they recalled and retained more information regarding the topic. Huy Hoang and Petraki (2016, p. 9) examined the use of humor in the Asian language classroom. The results of their study indicated that humor plays a significant role in the classroom. More than $76 \%$ (23 out of 30 ) of teachers participating in their study "made explicit attempts to use humor while the remaining seven teachers claimed during the interviews that they did use humor in their teaching, at least occasionally, depending on the context". However, no significant difference was reported between groups based on race or gender.

In order to examine the benefits of humor in the language classroom, Askildson (2005, p. 1) asked a number of language students and teachers to evaluate the employment of humor in their classrooms. The effectiveness of humor in "learning and instruction" in the classroom was strongly confirmed in his study. Abraham, et al. (2014, p. 2) similarly investigated students' perspective on the integration of humor in the classroom. According to the results, nearly all students $(\mathrm{n}=157 ; 97.5 \%)$ stated humor, if included relevantly in teaching practices in the classroom, is beneficial and also useful in better retention of the topic being taught $(n=141 ; 75.15 \%)$. Most of the students $(\mathrm{n}=158 ; 98.12 \%)$ stated that employment of humor in teaching practices paves the way for "a good teacher-student relationship". Most of them ( $=146$; $90.67 \%$ ) also stated that "a good sense of humor is an attribute of an effective teacher".

\subsection{Development of humor scales}

A number of humor scales, such as The Situational Humor Response Questionnaire (SHRQ), Coping Humor Scale (CHS), Sense of Humor Questionnaire (SHQ), and Multidimensional Sense of Humor Scale (MSHS) have been designed to presumably measure adaptive aspects of humor. These humor measures have been extensively utilized in past research on life events (Kuiper, Martin, \& Dance, 1992), well-being (Martin \& Lefcourt, 1984; Thorson, Powell, Sarmany-Schuller, \& Hampes, 1997), and coping with stress (Kuiper, Martin, \& Olinger, 1993; Overholser, 1992). 
"SHRQ and CHS are self-report measures of different aspects of sense of humor that were developed in the context of an investigation of the stress-moderating effects of humor" (Martin, 1996, p. 3). SHRQ measures the degree to which individuals tend to laugh or smile in different circumstances, while CHS is a measure to investigate how individuals rely on using humor while confronting stress. The focus of SHQ is to assess one's tendency to perceive and enjoy humor in their daily life. MSHS, meanwhile, has been produced to observe a wide range of humor-associated behaviors and perceptions. This measure is beneficial for comparing groups' use of humor to determine how sense of humor is likely to be correlated with different personality traits.

A myriad of studies has implemented the abovementioned measures, including SHRQ, CHS, SHQ, and MSHS, to investigate the use of humor on life events (Kuiper, Martin, and Dance, 1992), well-being (e.g., Martin \& Lefcourt, 1984; Thorson et al., 1997), and coping with stress (Kuiper, Martin, \& Olinger, 1993; Overholser, 1992). However, none of these self-report measures and scales, according to Martin, PuhlikDoris, Larsen, Gray, \& Weir (2003), consistently addresses the particular ways through which individuals employ or incorporate humor. The only exception, as they maintain, can be CHS, which does prioritize the application of humor as a coping strategy. So, eventually the developed measures fail to specifically evaluate utilizations of humor that are "potentially detrimental to psychosocial well-being, such as aggressive or avoidant humor". To give an example, Martin et al. (2003, p. 5) analyze a couple of typical humor scale items from the MSHS, thoroughly indicating that items such as "Uses of humor help me master difficult situations" or "I can often crack people up with the things I say", which are presumed to measure adaptive types of humor, are also likely to be incorporated by "individuals who frequently engage in potentially deleterious forms of humor such as sarcasm, disparagement humor, or humor used as a form of defensive denial".

Regarding the SHRQ and the CHS, Martin (1996, p. 16) points to the potentially culture specific items of the SHRQ and advises researchers to modify the items while administering the scale to the ones from the other cultures and to the different age groups. He also considers that the CHS is a limited "measure of the degree to which individuals make use of humor in coping with stressful situations, rather than as a general measure of the sense of humor". He suggests that "researchers considering using the SHRQ or CHS in their own study should bear in mind their range of applicability, as well as their limitations".

\subsection{The Humor Styles Questionnaire (HSQ)}

In an attempt to develop a measure that would take the various functions of humor into account, rather than particular personalities, Martin et al. (2003, p. 51) developed the Humor Styles Questionnaire (HSQ). Different from the aforementioned measures, in the HSQ "the interpersonal and intrapsychic functions of humor" used by individuals in their everyday lives are taken into account. According to them, these functions are particularly believed to be related to psychosocial well-being. Assessing 
different functions of humor, the HSQ is expected to encompass "greater proportion of the variance in aspects of mental health and well-being than previous self-report humor scales" (p. 51). As Schermer, Martin, Martin, Lynskey, \& Vernon (2013, p. 1) state, the HSQ measure "is based on the assumption that humor is not unique to particular personalities, but rather that individuals express humor in their daily lives in ways that reflect their broader personality traits".

The HSQ consists of 32 items, and concerns four different functions relating to individual differences in employing humor: affiliative, self-enhancing, aggressive, and self-defeating. Two of these dimensions (Self-enhancing and affiliative) are considered to be conducive to psychosocial well-being, while the other two dimensions (aggressive and self-defeating) are hypothesized as less gracious and potentially even detrimental to well-being. These four specific humor styles identified by Martin et al. (2003) are elaborated as follows:

\subsubsection{Affiliative humor}

Affiliative humor refers to the benign one aiming to strengthen the individual's social relationships with others. Based on narrating humorous remarks, cracking jokes and being involved in spontaneous humorous speech to entertain others, this type of humor is benignly adopted to reinforce relationships and enhance group cohesion without being malicious to oneself or others. To give an example, one is likely to use humorous language or funny narration to relieve any increasing tension. Therefore, this style of humor is a substantially favorable, tolerant utilization of humor affirming which aims to reinforce "interpersonal cohesiveness and attraction. This style of humor is expected to be related to extraversion, cheerfulness, selfesteem, intimacy, relationship satisfaction, and predominantly positive moods and emotions" (Martin et al., 2003, p. 7).

\subsubsection{Self-enhancing humor}

The self-enhancing dimension refers to another benign use of humor with the intention of enhancing the self. This type of humor acts as a confronting medium to make ones feel better about themselves. The individuals preferring to adopt this style of humor usually take a humorous attitude to life, and prefer to be frequently amused by the disparities in life, regardless as to how stressful the situation becomes. As a result, someone is likely to employ humor as a resource to handle stressful or tense situations or cope with negative or destructive emotions. In comparison to affiliative humor, as Martin et al. (2003, p. 8) underline, self-enhancing use of humor "has a more intrapsychic than interpersonal focus, and is therefore not expected to be as strongly related to extraversion. Given the focus on the regulation of negative emotion through humorous perspective-taking, this dimension is hypothesized to be negatively related to negative emotions such as depression and anxiety and, more generally, to neuroticism, and positively related to openness to experience, self-esteem, and psychological well-being." 


\subsubsection{Aggressive humor}

In contrast to affiliative and self-enhancing styles of humor, the aggressive dimension of humor is the first of two classified as injurious in style. This harnesses humor in order to enhance the self at the expense of others. Someone employing the aggressive humor style is likely to ridicule or deride others with the goal of selfenhancement. However, it is noteworthy that individuals who use an aggressive humor style may not be fully cognizant of the potentially harmful or negative consequences of this type of humor style. This style of humor may be also employed to manipulate other people by implying a threat while ridiculing (Janes \& Olson, 2000). Generally, this type of humor refers to the tendency of an individual to use humor without considering its potentially injurious effect on others, and involves compelling and irresistible utilization of humor. This type of humor is, according to Martin et al. (2003, p. 8), expected to be "positively related to neuroticism and particularly hostility, anger, and aggression, and negatively related to relationship satisfaction, agreeableness, and conscientiousness".

\subsubsection{Self-defeating humor}

The final form of humor is used to enhance relationships at the expense of oneself. According to Martin et al. (2003), this is the self-defeating dimension of humor. This humor style involves an individual employing humor to belittle themselves. To give an example, an individual may disparage or ingratiate himself or make fun of his own intelligence with the intention of receiving the approval of others. Hence, this injurious style of humor may result in pleasing others, but the approval comes at a price. The individual may laugh along with others when being derided or ridiculed. This style of humor is hypothesized "to be positively related to neuroticism and negative emotions such as depression and anxiety, and negatively related to relationship satisfaction, psychological well-being, and self-esteem" (Martin et al., 2003, p. 8).

\subsection{Studies on humor using $H S Q$}

Schermer et al. (2013, p. 2) maintain that affiliative humor, or employing humor to improve social relationships, has been indicated "to correlate positively with extraversion and openness". Self-enhancing humor, or employing humor to lessen "personal stress, has generally been found to be positively associated with extraversion, agreeableness and openness, and negatively with neuroticism". Aggressive humor, as the first injurious humor style, referring to deriding others in a belittling manner, meanwhile, has been reported "to be positively correlated with extraversion and neuroticism and negatively correlated with agreeableness, conscientiousness, and honesty-humility. Self-defeating humor, or using excessively self-disparaging humor in an attempt to ingratiate oneself with others, has been found to be positively associated with neuroticism and negatively with conscientiousness".

Researchers in the field conducted numerous studies searching into the relationship between humor styles and numerous variables (e.g., Ford, McCreight, \& Richardson, 
2014; Schermer et al., 2013; Veselka, Schermer, Martin, \& Vernon, 2010; Vrabel, Zeigler-Hill, \& Shango, 2016). The results of the studies indicated that humor styles had correlation with personality (Martin et al., 2012; Schermer et al., 2013; Veselka et al., 2010) depressive symptoms, life satisfaction (Dyck and Holtzman, 2013; Tucker et al., 2013).

The studies conducted in the Turkish context where the current study was carried out also investigated the correlation between humor styles and various variables. In one of the studies conducted by Bilge and Saltuk (2007), Turkish college students' subjective well-beings, trait anger and trait anxiety based on their humor styles were investigated. Their results indicated that the subjective well-beings of participants who preferred affiliative and self-enhancing humor styles were higher. In contrast, they also obtained lower trait angry and anxiety scores. The results also indicated that the trait anger scores of the participants adopting aggressive humor styles were higher, while their subjective well-being scores were lower. The trait anxiety of the participants preferring self-defeating humor style appeared to be higher. In addition, socio demographic variables, loneliness, self-esteem and their relation to humor styles were investigated in the studies carried out by Tumkaya (2011), Cecen (2007), and Ozyesil (2012). In Tumkaya's (2011) study, the use of aggressive and self-defeating humors were reported to be significantly greater in male students than female students. In contrast, the use of affiliative and self-enhancing humors was not found to be significantly different between the two groups of the participants. Moreover, in Cecen's (2007) study, it was found out that there were strong negative correlations between loneliness and affiliative and self-enhancing humor styles, and moderate positive correlations between loneliness and self-defeating humor style. In Ozyesil's (2012) study, self-esteem was reported to be positively correlated with positive affection, while self-esteem was found to be negatively correlated with negative affect.

Despite numerous studies on employing humor as a tool in teaching English in different parts of the world, studies on the humor styles of teachers themselves are scarce. Studies which have made enquiries about teachers' humor styles are limited to areas such as primary school teaching, early childhood education, or psychological counseling and guidance (Altinkurt \& Yilmaz, 2011; Aydin, 2015; Tras, Arslan, \& Tas, 2011) in Turkey.

This paper thus attempts to bridge the gap in exploring the humor styles of teachers of EFL teachers in Turkish context. As to provide some in-depth perspectives on teachers' humor styles and contribute to the related literature on humor studies, this study examines the following research questions:

1. Is there a difference between male and female instructors with regard to the humor styles they adopt?

2. Does the educational level of the Turkish EFL instructor affect their preference of humor styles while interacting with the students in the classroom?

3. Is the age of the instructor an influential factor in their adoption of humor styles? 


\section{Method}

The study was conducted on a total of 64 instructors who were randomly selected from the total population of Turkish EFL teachers working at various universities in Turkey. The data for the current study was gathered through the Humor Styles Questionnaire as devised by Martin et al. (2003). In the analysis of quantitative data, t-test and one-way ANOVA were used.

\subsection{Participants}

The instructors participating in this study were purposefully selected from the total population of Turkish EFL teachers teaching at different private and state universities in Turkey. A total number of 64 instructors voluntarily took part in the study. All participants had stated that they used humor as a part of their teaching practice. In addition, the participants stated that they had no knowledge of their own humor style at the time of the study.

\subsection{Materials}

In this study, data was collected through the use of a questionnaire (Humor Styles Questionnaire). In order to explore the humor styles of EFL teachers, English version of The Humor Styles Questionnaire identified by Martin et al. (2003) was used as the data collection tool. In their study, the scale indicated adequate internal consistencies ranging from .77 to .81. A Turkish version was used, as developed by Yerlikaya in 2003. The Cronbach alpha coefficient scores of the questionnaire were reported to be ranging from .67 to .78. Both English and Turkish versions were shared though an online questionnaire developing website (www.surveymonkey.com). The Humor Styles Questionnaire is a 32 item self-report scale addressing four styles of humor: affiliative, self-enhancing, aggressive, and self-defeating. Items in the questionnaire are structured in 7 point Likert scale format. A t-test was run in order to find out whether gender plays a significant role in terms of using humor. Added to that, a oneway ANOVA was conducted to investigate the possible role of age and educational background of the instructors in their preferred use of humor in the classroom.

\section{Results}

The first question aimed to see whether there was any difference between male and female participants in terms of using humor styles. In so doing, the male and female participants' answers to four-style questionnaire identified by Martin et al. (2003) were held to close scrutiny. In order to compare the scores obtained from the male participants with those of the female ones, a $t$-test was conducted to investigate the possible difference between them. Descriptive statistics for the two groups presented in Table 1 showed that the male participants had a higher mean in affiliative $(M=$ 40.61, $S D=7.86)$, self-enhancing $(M=29.11, S D=4.60)$, and self-defeating $(M=$ 31.66, $S D=3.97$ ) in comparison to the female participants, while it was in aggressive humor style that the female participants scored a higher mean $(M=28.89, S D=7.28)$ than male participants $(M=27.66, S D=6.08)$. 
Table 1. Descriptive Statistics for the Gender's Humor Styles

\begin{tabular}{lllll}
\hline Humor Style & Group & $\mathrm{N}$ & Mean & SD \\
\hline Affiliative & Male & 18 & 40.61 & 7.86 \\
& Female & 46 & 39.69 & 8.73 \\
Self-enhancing & Male & 18 & 29.11 & 4.60 \\
& Female & 46 & 28.36 & 3.16 \\
Aggressive & Male & 18 & 27.66 & 6.08 \\
& Female & 46 & 28.89 & 7.28 \\
Self-defeating & Male & 18 & 31.66 & 3.97 \\
& Female & 46 & 29.32 & 5.33 \\
\hline
\end{tabular}

The results obtained from the $t$-test run (Table 2) indicated no significant difference between the scores of male and female participants in use of affiliative $t(62)=.38, p<$ .70 or self-enhancing humor $t(62)=.73, \quad p<.43$. Neither was any significant difference confirmed between the scores of male and female participants with aggressive $t(62)=-.63, p<.53$ and self-defeating humor styles $t(62)=1.68, p<.097$.

Table 2. T-Test Results between the Male and the Female Groups' Humor Style

\begin{tabular}{|c|c|c|c|c|c|c|c|}
\hline & & $\mathrm{F}$ & Sig & $\mathrm{t}$ & $\mathrm{df}$ & Sig. (2-tailed) & Mean Difference \\
\hline Affiliative & $\begin{array}{l}\text { Equal variances } \\
\text { assumed }\end{array}$ & .35 & .55 & .38 & 62 & .70 & .91 \\
\hline Self-enhancing & $\begin{array}{l}\text { Equal variances } \\
\text { assumed }\end{array}$ & .06 & .79 & .73 & 62 & .46 & .74 \\
\hline Aggressive & $\begin{array}{l}\text { Equal variances } \\
\text { assumed }\end{array}$ & .59 & .44 & -.63 & 62 & .53 & -1.22 \\
\hline Self-defeating & $\begin{array}{l}\text { Equal variances } \\
\text { assumed }\end{array}$ & .65 & .42 & 1.68 & 62 & .097 & 2.34 \\
\hline
\end{tabular}

The second question addressed the effect of the instructors' educational level (bachelor's, master's, and doctorate) on their preference of employing humor styles. As indicated in Table 3, the results obtained from the one-way ANOVA for the affiliative humor style indicated no significant difference among the scores of instructors holding a bachelor's $(M=39.57, S D=7.67)$, those with a master's $(M=39.69, S D=9.34)$, or those with a doctorate degree $(M=42.42, S D=5.91), F(2,61)=.332, p>.05$. In terms of self-enhancing humor style, neither was there a significant difference among the scores of instructors with the bachelor's $(M=28.42, S D=3.07)$, master's $(M=28.83$, $S D=4.06)$, or doctorate degree $(M=27.71, S D=2.62), F(2,61)=.303, p>.05$. 
Table 3. One-Way Anova for the Educational Level of the Instructors Adopting Affiliative and SelfEnhancing Humor Styles

\begin{tabular}{lllllll}
\hline & & SS & df & MS & F-value & Sig. \\
\hline Affilative & Between Groups & 48.36 & 2 & 24.18 & .332 & .719 \\
& Within Groups & 4446.49 & 61 & 72.89 & & \\
& Total & 4494.85 & 63 & & & \\
Self-enhancing & & & & & \\
& Between Groups & 8.038 & 2 & 4.019 & .303 & .740 \\
& Within Groups & 809.57 & 61 & 13.272 & & \\
& Total & 817.60 & 63 & & & \\
\hline
\end{tabular}

As shown in Table 4, participants with a doctorate degree obtained the highest score $(M=42.42)$ with regard to use of affiliative humor, while participants with a master's degree received the highest score $(M=28.83)$ in adopting self-enhancing humor.

Table 4. Descriptive Statistics for the Educational Level of the Instructors Adopting Affiliative and SelfEnhancing Humor Styles

\begin{tabular}{lllll}
\hline Humor Style & Educational Level & N & Mean & SD \\
\hline Affilative & BA & 21 & 39.57 & 7.67 \\
& MA & 36 & 39.69 & 9.34 \\
& Ph.D. & 7 & 42.42 & 5.91 \\
Self-enhancing & BA & 21 & 28.42 & 3.07 \\
& MA & 36 & 28.83 & 4.06 \\
& Ph.D. & 7 & 27.71 & 2.62 \\
\hline
\end{tabular}

The results obtained from the one-way ANOVA (Table 5) for the aggressive humor style showed no significant difference between instructors with a bachelor's $(M=$ 28.09, $S D=5.02)$, those with a master's $(M=29.19, S D=7.88)$, and those with a doctorate degree $(M=26.57, S D=7.16), F(2,61)=.476, p>.05$. With regard to employing self-defeating humor style, similarly, no significant difference was seen between the scores of instructors with a bachelor's $(M=30.95, S D=5.03)$, those with a master's $(M=29.33, S D=5.26)$, and those with a doctorate degree $(M=30.42, S D=$ 4.19), $F(2,61)=.699, p>.05$.

Table 5. One-Way Anova for the Educational Level of the Instructors Adopting Aggressive and SelfDefeating Humor Styles

\begin{tabular}{lllllll}
\hline & SS & df & MS & F-value & Sig. \\
\hline Aggressive & Between Groups & 46.69 & 2 & 23.33 & .476 & 623 \\
& Within Groups & 2991.15 & 61 & 49.035 & & \\
& Total & 3037.85 & 63 & & & \\
Self-defeating & & & & & \\
& Between Groups & 36.31 & 2 & 18.159 & .699 & .501 \\
& Within Groups & 1584.66 & 61 & 25.978 & & \\
& Total & 1620.98 & 63 & & & \\
\hline
\end{tabular}


With regard to the use of injurious humor styles (aggressive and self-defeating), MA holders obtained the highest score $(M=229.19)$ with regard to employing aggressive humor style. In contrast, BA holders had the highest score $(M=30.95)$ in terms of using self-defeating humor style in the classroom (Table 6).

Table 6. Descriptive Statistics for the Educational Level of the Instructors Adopting Aggressive and Self Defeating Humor Styles

\begin{tabular}{lllll}
\hline Humor Style & Educational Level & N & Mean & SD \\
\hline Aggressive & BA & 21 & 28.09 & 5.02 \\
& MA & 36 & 29.19 & 7.88 \\
& Ph.D. & 7 & 26.57 & 7.16 \\
Self-defeating & BA & 21 & 30.95 & 5.03 \\
& MA & 36 & 29.33 & 5.26 \\
& Ph.D. & 7 & 30.42 & 4.19 \\
\hline
\end{tabular}

The third research question addressed the significance of the instructors' age (bachelor's, master's, and doctorate) on their preference of adopting different humor styles. Similarly to the first and second research questions, the results obtained from the one-way ANOVA for the affiliative humor style indicated no significant difference among the scores of the instructors who were between twenty to twenty five $(M=$ $37.75, S D=13.27)$, those between twenty six to thirty one $(M=37.23, S D=9.56)$, those between thirty two to thirty seven $(M=39.36, S D=5.63)$, those between thirty eight to forty three $(M=44.78, S D=6.93)$, those between forty four to forty nine $(M=$ $41, S D=10.12)$, and the final group who were between fifty to fifty nine years old ( $M$ $=44), F(5,58)=1.54, p>.05$. Consequently, no significant difference was seen among the above-mentioned aging groups in terms of employing the other humor styles: selfenhancing $F(5,58)=2.31, p>.05$, aggressive $F(5,58)=.51, p>.05$, and self-defeating $F(5,58)=.48, p>.05$. The descriptive statistics of the different aging group is presented in Table 7 .

As evident in Table 7, although there was no significant difference between the participants according to age, with regard to employing affiliative humor style participants aged 38 to 43 had a slightly higher than average scores $(M=44.78, S D=$ 6.93) while participants aged 26 to 31 years old obtained somewhat lower than average scores $(M=37.23, S D=9.56)$. In contrast, 26 to 31 -year-old participants obtained the highest score in self-enhancing humor style, while 20 to 25 year-old aging group received the lowest score in adopting self-enhancing humor style. Considering the injurious humor styles (aggressive and self-defeating), it can be seen that the participants aged 38 to 43 achieved the highest score $(M=30.57, S D=10.08)$, while the participants who were 50 to 55 years old obtained the lowest score $(M=23$, $S D=0$ ) with regard to employing the aggressive humor style in the classroom. 32 to 37-year-old participants were the highest-achievers $(M=30.84, S D=4.31)$, while 
participants aged 38-43 years old were the lowest-achievers in terms of using selfdefeating humor style in the classroom.

Table 7. Descriptive Statistics for the Age

\begin{tabular}{|c|c|c|c|c|}
\hline Humor Style & Age & $\mathrm{N}$ & Mean & $\mathrm{SD}$ \\
\hline \multirow[t]{7}{*}{ Affilative } & $20-25$ & 4 & 37.75 & 13.27 \\
\hline & $26-31$ & 21 & 37.23 & 9.56 \\
\hline & $32-37$ & 19 & 39.36 & 5.63 \\
\hline & $38-43$ & 14 & 44.78 & 6.93 \\
\hline & $44-49$ & 5 & 41 & 10.12 \\
\hline & $50-55$ & 1 & 44 & \\
\hline & Total & 64 & 39.95 & 8.44 \\
\hline \multirow{7}{*}{ Self-enhancing } & $20-25$ & 4 & 25.75 & 3.40 \\
\hline & $26-31$ & 21 & 30.19 & 4.38 \\
\hline & $32-37$ & 19 & 28.57 & 3.38 \\
\hline & $38-43$ & 14 & 27 & 1.41 \\
\hline & 44-49 & 5 & 27.80 & 2.68 \\
\hline & $50-55$ & 1 & 32 & \\
\hline & Total & 64 & 28.57 & 3.60 \\
\hline \multirow[t]{7}{*}{ Aggressive } & $20-25$ & 4 & 28.25 & 6.29 \\
\hline & $26-31$ & 21 & 28.95 & 5.37 \\
\hline & $32-37$ & 19 & 27.26 & 5.94 \\
\hline & $38-43$ & 14 & 30.57 & 10.08 \\
\hline & $44-49$ & 5 & 27.40 & 7.95 \\
\hline & $50-55$ & 1 & 23 & \\
\hline & Total & 64 & 28.54 & 6.94 \\
\hline \multirow[t]{7}{*}{ Self-defeating } & $20-25$ & 4 & 29.25 & 7.41 \\
\hline & $26-31$ & 21 & 30.19 & 6.54 \\
\hline & $32-37$ & 19 & 30.84 & 4.31 \\
\hline & $38-43$ & 14 & 28.28 & 3.66 \\
\hline & $44-49$ & 5 & 31.20 & 2.28 \\
\hline & $50-55$ & 1 & 30 & \\
\hline & Total & 64 & 29.98 & 5.07 \\
\hline
\end{tabular}

\section{Conclusion}

This study investigated university instructors' perceptions of the roles of humor in ELT classroom, their practices of humor in their classrooms, and teachers' preferences in respect of using humor types in Turkey. In so doing, three research questions were developed to investigate whether university instructors' gender, their educational level, and age play a significant role in employing Martin et al.'s (2003) humor styles.

A close scrutiny of the previous studies conducted in Turkey indicates a number of differences and similarities between this and previous research. For example, in a study to investigate humor styles of primary school teachers, Altinkurt and Yilmaz (2011, p. 1) used the HSQ scale and examined the humor styles of teachers and differences while considering a number of variables. According to the results of the study, the highest percentage of humor style in primary school teachers was reported to be closest to the "affiliative humor style, followed by self-enhancing, aggressive humor and self-defeating humor styles". There was also a significant difference between the male and female participants in respect of employing the aggressive and 
self-defeating humor styles. However, there was no significant difference based on the age of participants in terms of using humor styles. In contrast to our study, in which there was no significant difference between male and female participants (university instructors) with regard to adopting humor styles in the classroom, Altinkurt and Yilmaz (2011) reported a significant difference between the male and female participants (primary school teachers). As in our study, their investigation also found little evidence to suggest the age factor played a significant role in influencing the preference of the participants to use humor styles in the classroom.

In another study, Kilic (2016) investigated the percentages and frequencies of humor used by middle school Turkish teachers, and their beliefs and attitudes about humor. Results showed no significant difference among the opinions of teachers with regard to the employment of humor in middle school Turkish courses and their seniority in the profession. As in our study, in which there showed no significant difference between male and female university instructors with regard to adopting humor styles in the classroom, Kilic's (2016) study indicated no significant difference between the opinions of the male and those of the female secondary school teachers in terms of using humor in the classrooms. Nor did the seniority in the profession play a significant role regarding the use of humor in the course. A different study conducted by Agcam (2017) also underlines the perception of Turkish instructors toward the employment of humor in the educational settings. Agcam's (2017, p. 1) study, aiming to investigate the beliefs of English language instructors on the employment of humor in tertiary education, indicated that the instructors tended to possess "positive perceptions" with regard to the employment of humor in language classrooms; however, they displayed a slight reluctance with its employment.

As the underlying assumption of the current study indicates, humor should be regarded as an important tool in teaching and learning a language. In doing so, humor styles of teachers and learners should be considered as a part of the process of using humor in the language classroom. The current study, which looks into Turkish EFL teachers' humor styles, serves to encourage teachers to gain an awareness of the effect of their own humor style, encouraging revision where needed. By becoming aware of their humor styles, teachers can develop better insights into how they can take advantage of the benefits the use of humor provides in the language classroom. Like exploring teachers' various beliefs and strategies, researching humor styles should be an indispensable component of pre and in-service teacher training programs, teacher development workshops and teachers' own attempts to develop themselves.

Despite the high educational level of the majority of the instructors, that is, 37 with masters' and 7 with doctorate degrees in this study, there was little difference when it came to humor between them and those at a bachelor's level. This is likely to illuminate lack of focus on personality traits in the curricula implemented at universities in their program. More emphasis needs to be given to educating and familiarizing instructors with the facilitating role of the humor in the classroom, the multifaceted nature of humor styles, and, of course, precautions that need to be 
exercised. In the syllabi of courses which focus on teacher training, classroom managements, and other relevant courses, the integration of humor types and creating consciousness of their utilization carry significant importance. This is due to the fact that, as the literature review indicates, an infinite number of facilitating characteristics are attributed to using humor in the classroom (Garner, 2003; Harmer, 2007; Huy Hoang \& Petraki, 2006; Oxford, 1999).

That age seemed to represent no contributing factor in using humor in the classroom was a surprising result. In this study, the younger instructors were hypothesized to be different from the senior ones, as a natural consequence of being more intimate to the student generation. This familiarity with the priorities of the students can be an invaluable facet in generating the learning opportunities and implementing the different humor styles. As a result, they are expected to rely more on humor styles than the elderly instructors..

The cognitive and affective benefits of using humor in the language classroom are undeniable, as most studies advocate that humor greases the wheels of the learning process in classrooms in general, and language classrooms in particular. The conclusions drawn from the findings suggest that the humor styles of instructors need to be put under closer scrutiny. The personality traits of the instructors (e.g., intelligence) as a determining factor in preferring humor styles also appear to be fruitful avenues for future research.

\section{References}

Abraham, R. R., Hande, V., Sharma, M. E. J., Wohlrath, S. K., Keet, C. C., \& Ravi, S. (2014). Use of humour in classroom teaching: Students' perspectives. Thrita, 3(2), 1-4.

Agcam, R. (2017). Investigating instructors' perceptions on the use of humour in higher education. European Journal of Education Studies, 3(2), 238-248.

Altinkurt, Y., \& Yilmaz, K. (2011). Humor styles of primary school teachers. Pegem Journal of Education and Instruction, 1(2), 1-8.

Askildson, L. (2005). Effects of humor in the language classroom: Humor as a pedagogical tool in theory and practice. Arizona Working Papers in SLAT, 12, 45-61.

Aydin, A. (2015). Identifying the relationship of teacher candidates' humor styles with anxiety and self-compassion levels. Eurasian Journal of Educational Research, 59, 1-16.

Berk, R. (1998). Professors are from mars, students are from snickers: How to write and deliver humor in the classroom and in professional presentations. Madison, WI: Magna Publications.

Bilge, F., \& Saltuk, S. (2007). Humor Styles, Subjective Well-beings, Trait Anger and Anxiety among University Students in Turkey. World Applied Sciences Journal, 2(5), 464-469.

Cecen, R. (2007). Humor styles in predicting loneliness among Turkish university students. Social Behavior and Personality: An International Journal, 35(6), 835-844.

Dornyei, Z. (2001). Motivational strategies in the language classroom. Cambridge: Cambridge University Press.

Dyck, K. T., \& Holtzman, S. (2013). Understanding humor styles and well-being: The importance of social relationships and gender. Personality and Individual Differences, 55, $53-58$. 
Ford, T. E., McCreight, K. A., \& Richardson, K. (2014). Affective style, humor styles, and happiness. Europe's Journal of Psychology, 10, 451-463.

Garner, R. (2003). Which came first, the chicken or the egg? A foul metaphor for teaching. Radical Pedagogy, 5(2), 205-212.

Garner, R. (2005). Humor, Analogy, and Metaphor: H.A.M. it up in Teaching. Radical Pedagogy, 6(2). Retrieved from http://www.radicalpedagogy.org/radicalpedagogy /Humor, Analogy,_and_Metaphor_H.A.M._it_up_in_Teaching.html

Garner, R. (2006). Humor in pedagogy: How ha-ha can lead to aha! College Teaching, 54(1), $177-180$.

Gonzalez, G. (2014). Ten ways to sabotage your classroom management. Retrieved from https://www.middleweb.com /19037/10-ways-sabotage-classroom-management/

Harmer, J. (2007). The practice of English language teaching. (4th ed.). Essex: Longman.

Huy Hoang, P., \& Petraki, E. (2016). Do Asian EFL teachers use humour in the classroom? A case study of Vietnamese EFL university teachers. System, 61, 98-109.

Janes, L. M., \& Olson, J. M. (2000). Jeer pressure: The behavioral effects of observing ridicule of others. Personality and Social Psychology Bulletin, 26, 474-485.

Kilic, Y. (2016). The views of Turkish teachers on the use of humor in secondary schools. Educational Research and Reviews, 11(9), 945-956.

Kuiper, N. A., Martin, R. A., \& Dance, K. (1992). Sense of humor and enhanced quality of life. Personality and Individual Differences, 13(12), 1273-1283.

Kuiper, N. A., Martin, R. A., \& Olinger, L. J. (1993). Coping humour, stress, and cognitive appraisals. Canadian Journal of Behavioral Science, 25, 81-96.

Martin, R. A., Lastuk, J. M., Jeffery, J., Vernon, P. A., \& Veselka, L. (2012). Relationships between the dark triad and humor styles: A replication and extension. Personality and Individual Differences, 52, 178-182.

Martin, R. A., \& Lefcourt, H. M. (1984). The situational humor response questionnaire: Quantitative measure of sense of humor. Journal of Personality and Social Psychology, 47, $145-155$

Martin, R. A., Puhlik-Doris, P., Larsen, G., Gray, J., \& Weir, K. (2003). Individual differences in the uses of humor and their relation to psychological well-being: Development of the humor styles questionnaire. Journal of Research in Personality, 37, 48-75.

Martin, R. A. (1996). The situational humor response questionnaire (SHRQ) and coping humor scale (CHS): A decade of research findings. Humor, 9, 251-272.

McNamara, T. (2004). Language Testing. In A. Davies, \& C. Elder (Eds.), The handbook of applied linguistics (p. 763-783). Blackwell.

Overholser, J. S. (1992). Sense of humor when coping with life stress. Personality and Individual Differences, 13(7), 799-804.

Oxford, R. L. (1999). Anxiety and the language learner: new insights. In J. Arnold (Ed.), Affect in language learning (pp. 58-67). Cambridge: Cambridge University Press.

Ozyesil, Z. (2012). The prediction level of self-esteem on humor style and positive-negative affection. Psychology, 3(8), 638-641.

Schermer, J.A., Martin, R. A., Martin, N. G., Lynskey, M., \& Vernon, P. A. (2013). The general factor of personality and humor styles. Personality and Individual Differences, 54, 890-893.

Steele, K. E. (1998). The positive and negative effects of the use of humor in the classroom setting (Unpublished MA thesis). Salem, Teikyo University.

Sudol, D. (1981). Dangers of classroom humour. English Journal, 70(6), 26-28. 
Thorson, J. A., \& Powell, F. C. (1993). Development and validation of a multidimensional sense of humor scale. Journal of Clinical Psychology, 48, 13-23.

Thorson, J. A., Powell, F. C., Sarmany-Schuller, I., \& Hampes, W. P. (1997). Psychological health and sense of humor. Journal of Clinical Psychology, 53, 605-619.

Traş, Z., Arslan, C., \& Mentiş Taş, A. (2011). Öğretmen adaylarında mizah tarzları, problem çözme ve benlik saygısının incelenmesi [Analysis of humor styles, problem solving and selfesteem of prospective teachers]. International Journal of Human Sciences, 8(2), 716-732.

Tucker, R. P., Wingate, L. R., O’Keefe, V. M., Slish, M. L., Judah, M. R., \& Rhoades-Kerswill, S. (2013). The moderating effect of humor style on the relationship between interpersonal predictors of suicide and suicidal ideation. Personality and Individual Differences, $54,610-615$.

Tumkaya, S. (2011). Humor styles and socio-demographic variables as predictors of subjective well-being of Turkish university students. Education and Science, 36(160), 158-170.

Veselka, L., Schermer, J. A., Martin, R. A., \& Vernon, P. A. (2010). Relations between humor styles and the dark triad traits of personality. Personality and Individual Differences, 48, $772-774$.

Vrabel, J. K., Zeigler-Hill, V., \& Shango, R. (2016). Spitefulness and humor styles. Personality and Individual Differences, 105, 238-243.

Yerlikaya, E. (2003). A study on the adaptation of humor styles questionnaire (Unpublished master dissertation). Institute of Social Sciences, Adana: Cukurova University.

Ziv, A. (1988). Teaching and learning with humor: Experiment and replication. Journal of Experimental Education, 57(1), 5-15.

\section{Copyrights}

Copyright for this article is retained by the author(s), with first publication rights granted to the Journal.

This is an open-access article distributed under the terms and conditions of the Creative Commons Attribution license (CC BY-NC-ND) (http://creativecommons.org/licenses/by-nc-nd/4.0/). 